\title{
DEVELOPING CURRICULUM AND TASKS FOR TEACHING READING
}

\author{
Ella Wulandari \\ Yogyakarta State University
}

\begin{abstract}
This paper is aimed at proposing a curriculum and task design for teaching reading to students of an English teacher training. The curriculum discusses the needs and context analysis, goals, objectives, beliefs, content organization, task design, learning assessment and evaluation of the course. While being skill-oriented on one hand, the curriculum works towards a more process or discourse-oriented design. This is done to cater for the needs to build students' reading skills, understanding of text's construction and positive attitudes towards reading as not merely a means of acquiring a full command in the target language but also a tool to access knowledge and advancement.
\end{abstract}

Key words: reading, curriculum and task design

\section{INTRODUCTION}

In English as a foreign language (EFL) setting, reading has often been found to be the most accessible exposure to the target language (Celce-Muria \& Olshtain, 2000). Reading texts written in the target language (TL) serves not only as its authentic materials readily to learn and access but also a representation of its culture. According to Celce-Muria \& Olshtain (2000), reading in FL requires readers to deal with some difficulties including global processing, linguistic (lexical and grammatical), and discourse difficulties, resulting not only from different linguistic system but also different conventions of writing which are culturally specific (pp.127-133). They argue FL readers thus need to be equipped with reading skills/strategies along with knowledge of the TL, the world and the text discourse. 
Emphasis on reading skills/strategies has also been central to the teaching of reading at the English Education Study Program (EESP), English Education Department, Faculty of Languages and Arts, State University of Yogyakarta, Indonesia. The EESP is used to offer a teacher-preparatory course and its most important institutional goal has been to produce English language teachers and specialists. As such, the goal of reading is twofold. It is to make learners become an effective reader as part of becoming a proficient English speaker and to prepare them for future job employments. While teaching or academic-related jobs are the profession the students mostly aspire to, the Department offers a specialization in Translation Studies, English for Children, English for Business, Advanced TEFL (Teaching English as a Foreign Language) or Advanced Linguistics. Selecting one of the specializations is done in semester 6 . Until then, students should be exposed to various reading texts and topics. Reading class goes from Reading I to IV. This curriculum is however specifically developed for Reading II course.

\section{DISCUSSION}

Within the institutional contexts, the course is also situated within a narrower context involving aspects such as people, classroom setting, teaching resources, time and the nature of the course (Graves, 2000). Reading II is compulsory and offered in semester two. It requires the completion of Reading I. Reading I and II are designed to place solid foundation of reading skills/strategies in different types of reading activities that allow students to read effectively and fast. It contains 16 meetings (@100 minutes) with mid and final semester tests inclusive in 16 teaching weeks. A class is composed of 20 to 25 students. Having been studying for one semester in the Department, their proficiency is by large at intermediate level. Specifically, most of them would be at stage B1 of Nunan's (2004) self-assessment grid, where they are expected to be able to 'understand texts that consist of mainly of high frequency every day or job related language' and 'understand the description of events, feelings and wishes in personal letters' (p.210). Concerning their morphological development, Krashen's (Krashen, 1977) Morpheme Order Studies reveal that with B1 level of reading, the students have been between stage 3 to 4 where they have acquired past irregular and are about to learn past regular(-ed).

While further developing reading skills introduced in Reading I, Reading II also aims at enabling students to perform speed reading (PBI Curriculum 
Document, 2009). Such aims, Celce-Muria and Olshtain argue, are appropriate for EFL students. They claim that developing and raising awareness of and reading skills/strategies in both top-to-down and bottom-up reading approaches allow FL readers to select 'individual compensatory techniques' that help them solve linguistics and content insufficiency (2000, p. 122). While content deficiency has to do with knowledge of the world and text genre as readers process a text globally, linguistic inadequacy relates to skills in 'decode words and letters rapidly in a bottom-up fashion' (van Dijk \& Kintsch, 1983 in Celce-Muria \& Olshtain, 2000). The course thus embraces that 'good readers constantly integrate top-down and bottom-up processing techniques' (Celce-Muria \& Olshtain, 2000, p.123). While the first technique employs readers' schemata or prior knowledge of content and text types, and their expectations, the later is driven by linguistic data where readers rely heavily on semantic and syntactical information available in the text to interpret it.

The course's aims and objectives are formulated using a combination of KASA and Stern's concept of transfer (1992) with capacity to be dynamic and flexible towards learners' and learning needs (Graves, 2000; Richards, 2001). The frameworks are selected for embracing cognitive, linguistic and affective learning principles (Brown, 1994) and allowing the co-development of other language skills through transfer of skills. The aims and objectives include:

\begin{tabular}{|c|c|}
\hline Aims & Objectives \\
\hline $\begin{array}{l}\text { Knowledge } \\
\text { a. Understand various reading } \\
\text { skills/strategies } \\
\text { b. Understand linguistic and } \\
\text { discourse competences required } \\
\text { and relevant to utilizing specific } \\
\text { reading skills/strategies. }\end{array}$ & $\begin{array}{l}\text { 1. Associate certain reading purposes with specific } \\
\text { reading skills/strategies. } \\
\text { 2. Relate and associate grammatical and lexical } \\
\text { aspects of language necessary to perform specific } \\
\text { reading skills/strategies. } \\
\text { 3. Identify generic structures of different text types } \\
\text { and registers associated with them. }\end{array}$ \\
\hline $\begin{array}{l}\text { Awareness } \\
\text { Raise students awareness of } \\
\text { reading skills/strategies and of } \\
\text { their importance }\end{array}$ & $\begin{array}{l}\text { Evaluate their own comprehension when using and not } \\
\text { using appropriate reading skills/strategies. }\end{array}$ \\
\hline
\end{tabular}




\begin{tabular}{|c|c|}
\hline $\begin{array}{l}\text { Skills } \\
\text { a. Develop reading skills for } \\
\text { effective reading }\end{array}$ & $\begin{array}{l}\text { 1. Draw on prior knowledge as appropriate to assist } \\
\text { comprehension. } \\
\text { 2. Recognize discourse-level relationship and use this } \\
\text { information to build and support comprehension. } \\
\text { 3. Combine clause-level meanings to build a larger } \\
\text { meaning relationship within a text. } \\
\text { 4. Draw meaning from phrase- and clause-level } \\
\text { grammatical information. } \\
\text { 5. Draw selective extraction of relevant points from a } \\
\text { text. } \\
\text { 6. Use inferences of various types and to monitor } \\
\text { comprehension in line with reading goals. }\end{array}$ \\
\hline b. Develop speed reading skills & $\begin{array}{l}\text { 1. Use scanning and skimming. } \\
\text { 2. Practice rapid recognition at word, phrase and } \\
\text { sentence levels. }\end{array}$ \\
\hline $\begin{array}{l}\text { Attitudes } \\
\text { a. Develop positive attitudes } \\
\text { toward reading and reading } \\
\text { skills/strategies use. }\end{array}$ & $\begin{array}{l}\text { Reflect on everyday reading activities in terms of } \\
\text { effectiveness of strategies used and share students } \\
\text { own reflection to others. }\end{array}$ \\
\hline $\begin{array}{l}\text { b. Develop enthusiasm for } \\
\text { independent reading. }\end{array}$ & Read independently on students own initiatives. \\
\hline $\begin{array}{l}\text { Transfer } \\
\text { Transfer reading skills/strategies to } \\
\text { other language skills. }\end{array}$ & $\begin{array}{l}\text { Apply reading skills/strategies to other skill(s) } \\
\text { (speaking, listening or writing) and/or to L1 reading } \\
\text { activities. }\end{array}$ \\
\hline
\end{tabular}

This curriculum believes in the fact that language is a means of communication. Communication is realized through texts that mediate discourse processes (Widdowson, 1984 cited in Celce-Muria \& Olshtain, 2000). As language (in forms of written or spoken texts) and culture are inseparable, learning a language is also learning its societies' culture. With regards to reading, Grabe (2009, p.137) argues that

Institutional and cultural expectations shape the literacy events that are enacted in a given society, the types of texts that are commonly and preferentially produced and read, the reasons why people read texts, the ways texts tend to be interpreted, and the literacy experiences that a learner accumulates.

In short, texts are a product of culture whose interpretation requires understanding of the conventions of related discourses in the given culture. 
Meanwhile, language is also believed to be best learnt in interaction i.e. in using the language to interact with others (Vigotsky, 1978 cited in Lightbown \& Spada, 2006). While interacting in the target language (TL) optimizes the students' zone of proximal development (ZPD), having ample of opportunities to practice language skills accelerates the transformation of proceduralized knowledge into automatized knowledge (DeKeyser, 2007). DeKeyser argues that according to acquisition skill theory (AST), language skills acquisition "develop from initial representation of knowledge (declarative), through initial changes in behaviour (proceduralized), to eventual fluent, spontaneous, largely effortless and highly skilled behaviour (automatized)" (p.97). This automatization is a result of practices and indicated with accurate, stable and fast performance of given skills, though unnecessarily error free. In accelerating proceduralization to automatization, teachers should then play facilitative roles whose task is mainly to promote active participation on the part of learners. In so doing, it is important for teachers to build learners' intrinsic or integrative motivations and address learning strategies and autonomy (Brown, 1994).

There is recognition that reading is an active and purposeful process (Grabe, 2009; Grellet, 1981; Klapper, 2006). As a reader, learners are to actively draw meaning from a text 'any stretch of spoken or written language that is meaningful in a social context' (Thai, 2009, p.2). Texts are created using the conventions of grammar, organization and context bound to the given discourse community (Lin, 2006). Drawing meaning from a text demands understanding its discourse specificity. This calls for understanding of different text-types or genres (i.e. purposeful texts). Learners thus need to be informed and well equipped with skills to recognize distinct features of various genres to enhance their comprehension. While recognizing discourse features of certain text-types or genres is not always a necessity, it will serve as a departure point of meaning making processes. Genre-based approach thus lends its support to the course's being process-oriented (Graves, 2008).

Meanwhile, Grabe (2009, p.331) also states that the goal of reading instruction is 'to incorporate key component skills and knowledge into a coherent reading curriculum'. Reading is comprised of subskills, specific to reading strategies i.e. skimming, scanning, intensive, extensive and speed reading (Grellet, 2009; Klapper, 2006). The course thus needs to develop reading subskills that learners need to effectively perform a variety of everyday and academic reading 
tasks, so as to achieve various reading goals. Grellet adapts Munby's (1978) reading subskills to offer a variety of reading activities aiming at comprehension. Grabe bases his list of reading subskills from research findings in L1 and L2 reading. The subskills proposed by Grellet and Grabe will then serve as the main bases of organizing the contents of the course, while lending their support to the course's also being product-oriented (Graves, 2008). The following is the course's content organization adapted from Grabe (2009), Grellet (1981) and Thai (2009).

\begin{tabular}{|c|c|c|}
\hline Objectives & $\begin{array}{l}\text { Course contents } \\
\text { (reading skills) }\end{array}$ & $\begin{array}{c}\text { (Written) text } \\
\text { types }\end{array}$ \\
\hline $\begin{array}{l}\text { 1. Draw on prior } \\
\text { knowledge as } \\
\text { appropriate to assist } \\
\text { comprehension. }\end{array}$ & $\begin{array}{l}\text { a) Relate specific background knowledge to the } \\
\text { text at hand } \\
\text { b) Use co-text (e.g. pictures, graphs, quotation) } \\
\text { and context clues (beyond the text) to predict } \\
\text { and set expectations from reading a text }\end{array}$ & $\begin{array}{l}\text { News item } \\
\text { Exposition } \\
\text { Ads }\end{array}$ \\
\hline $\begin{array}{l}\text { 2. Recognize discourse- } \\
\text { level relationship and } \\
\text { use this information to } \\
\text { build and support } \\
\text { comprehension. }\end{array}$ & $\begin{array}{l}\text { a) Recognize indicators in discourse (distinct } \\
\text { generic structures of specific text types) } \\
\text { b) Recognize and identify patterns of paragraphs } \\
\text { including ordering of ideas (time, place, order } \\
\text { of importance), listing of details, comparison } \\
\text { and contrast, cause and effect } \\
\text { a) Outline the organization of a paragraph }\end{array}$ & $\begin{array}{l}\text { Recount } \\
\text { Narrative } \\
\text { Review }\end{array}$ \\
\hline $\begin{array}{l}\text { 3. } \\
\text { meanings to build a } \\
\text { larger meaning } \\
\text { relationship within a } \\
\text { text. }\end{array}$ & $\begin{array}{l}\text { b) Understand relations between the parts of a text } \\
\text { through lexical and grammatical cohesion } \\
\text { devices } \\
\text { c) Distinguish main ideas from supporting details }\end{array}$ & $\begin{array}{l}\text { Discussion } \\
\text { (argumentative } \\
\text { essay) }\end{array}$ \\
\hline $\begin{array}{l}\text { 4. Draw meaning from } \\
\text { phrase- and clause-level } \\
\text { grammatical } \\
\text { information. }\end{array}$ & $\begin{array}{l}\text { a) Understand relations within the sentence } \\
\text { b) Deduce the meaning and use of unfamiliar } \\
\text { lexical items from contextual and grammatical } \\
\text { clues) (e.g. punctuation, synonyms, antonyms, } \\
\text { examples, and general sentence clues, parts of } \\
\text { speech of related word(s)) } \\
\text { c) Understand explicitly stated information. } \\
\text { d) Understand information when not explicitly } \\
\text { stated } \\
\text { Understand the communicative value } \\
\text { (function) of sentences and utterances } \\
\text { Make inferences } \\
\text { e) Understand conceptual meaning. } \\
\text { Recognize clues that help locate or infer } \\
\text { conceptual meaning. }\end{array}$ & $\begin{array}{l}\text { Exposition } \\
\text { Report }\end{array}$ \\
\hline
\end{tabular}




\begin{tabular}{|c|c|c|c|c|}
\hline & $\begin{array}{l}\text { Draw selective } \\
\text { extraction of relevant } \\
\text { points of a text }\end{array}$ & & $\begin{array}{l}\text { Extract salient points to summarize } \\
\text { Transcode information to diagrammatic display }\end{array}$ & $\begin{array}{l}\text { Discussion } \\
\text { Description }\end{array}$ \\
\hline 6. & $\begin{array}{l}\text { Use inferences of } \\
\text { various types to monitor } \\
\text { comprehension in line } \\
\text { with reading goals. }\end{array}$ & & $\begin{array}{l}\text { Check ongoing comprehension by constantly } \\
\text { making inferences of a text } \\
\text { Set questions in mind to keep reading in line } \\
\text { with reading goals }\end{array}$ & $\begin{array}{l}\text { Procedure } \\
\text { Explanation }\end{array}$ \\
\hline 7. & $\begin{array}{l}\text { Use scanning and } \\
\text { skimming. }\end{array}$ & a) & $\begin{array}{l}\text { Skimming } \\
\text { Scanning to locate specifically required } \\
\text { information } \\
\text { Start with specific questions to answer by } \\
\text { reading a text }\end{array}$ & $\begin{array}{l}\text { News items } \\
\text { (classified ads) } \\
\text { Exposition } \\
\text { )*everyday } \\
\text { texts (manuals, } \\
\text { labels, recipes) }\end{array}$ \\
\hline 8. & $\begin{array}{l}\text { Practice rapid } \\
\text { recognition at word, } \\
\text { phrase and sentence } \\
\text { levels. }\end{array}$ & $\begin{array}{l}\text { a) } \\
\text { b) } \\
\text { c) } \\
\text { d) }\end{array}$ & $\begin{array}{l}\text { Identify content and functional words } \\
\text { Recognize rapidly identical words and phrases } \\
\text { Recognize rapidly key words/phrases, } \\
\text { repetitions, synonyms or registers of specific } \\
\text { text types } \\
\text { Recognize rapidly paragraph organization }\end{array}$ & $\begin{array}{l}\text { Anecdote } \\
\text { Exposition } \\
\text { )* everyday } \\
\text { reading texts } \\
\text { (timetables, } \\
\text { graphs, road } \\
\text { signs) }\end{array}$ \\
\hline 9. & $\begin{array}{l}\text { Apply reading } \\
\text { skills/strategies to other } \\
\text { skill(s) (speaking, } \\
\text { listening or writing) } \\
\text { and/or to L1 reading } \\
\text { activities }\end{array}$ & a) & $\begin{array}{l}\text { Draw comparison between L1 and L2 reading } \\
\text { skills and activities and identify their facilitative } \\
\text { or interfering roles } \\
\text { Evaluate learners own writing in terms of } \\
\text { phrasal-clausal-discourse level relationship } \\
\text { within similar text type(s) } \\
\text { Reflect on how learners can apply reading skills } \\
\text { to set expectation of what they will hear and to } \\
\text { help prepare their speech }\end{array}$ & $\begin{array}{l}\text { Students own } \\
\text { writing } \\
\text { Example of an } \\
\text { oral } \\
\text { presentation/ } \\
\text { lecture }\end{array}$ \\
\hline & $\begin{array}{l}\text { Draw on prior } \\
\text { knowledge as } \\
\text { appropriate to assist } \\
\text { comprehension. }\end{array}$ & & $\begin{array}{l}\text { Relate specific background knowledge to the } \\
\text { text at hand } \\
\text { Use co-text (e.g. pictures, graphs, quotation) } \\
\text { and context clues (beyond the text) to predict } \\
\text { and set expectations from reading a text }\end{array}$ & $\begin{array}{l}\text { News item } \\
\text { Exposition } \\
\text { Ads }\end{array}$ \\
\hline & $\begin{array}{l}\text { Recognize discourse- } \\
\text { level relationship and } \\
\text { use this information to } \\
\text { build and support } \\
\text { comprehension. }\end{array}$ & $\begin{array}{l}\text { a) } \\
\text { b) } \\
\text { a) }\end{array}$ & $\begin{array}{l}\text { Recognize indicators in discourse (distinct } \\
\text { generic structures of specific text types) } \\
\text { Recognize and identify patterns of paragraphs } \\
\text { including ordering of ideas (time, place, order } \\
\text { of importance), listing of details, comparison } \\
\text { and contrast, cause and effect } \\
\text { Outline the organization of a paragraph }\end{array}$ & $\begin{array}{l}\text { Recount } \\
\text { Narrative } \\
\text { Review }\end{array}$ \\
\hline & $\begin{array}{l}\text { Combine clause-level } \\
\text { meanings to build a } \\
\text { larger meaning } \\
\text { relationship within a } \\
\text { text. }\end{array}$ & b) & $\begin{array}{l}\text { Understand relations between the parts of a text } \\
\text { through lexical and grammatical cohesion } \\
\text { devices } \\
\text { Distinguish main ideas from supporting details }\end{array}$ & $\begin{array}{l}\text { Discussion } \\
\text { (argumentative } \\
\text { essay) }\end{array}$ \\
\hline
\end{tabular}




\begin{tabular}{|c|c|c|c|}
\hline $\begin{array}{l}\text { 13. Draw meaning from } \\
\text { phrase- and clause-level } \\
\text { grammatical } \\
\text { information. }\end{array}$ & \begin{tabular}{|l} 
c) \\
d) \\
e)
\end{tabular} & $\begin{array}{l}\text { Understand relations within the sentence } \\
\text { Deduce the meaning and use of unfamiliar } \\
\text { lexical items from contextual and grammatical } \\
\text { clues) (e.g. punctuation, synonyms, antonyms, } \\
\text { examples, and general sentence clues, parts of } \\
\text { speech of related word(s)) } \\
\text { Understand explicitly stated information. } \\
\text { Understand information when not explicitly } \\
\text { stated } \\
\text { Understand the communicative value } \\
\text { (function) of sentences and utterances } \\
\text { Make inferences } \\
\text { Understand conceptual meaning. } \\
\text { Recognize clues that help locate or infer } \\
\text { conceptual meaning. }\end{array}$ & $\begin{array}{l}\text { Exposition } \\
\text { Report }\end{array}$ \\
\hline $\begin{array}{l}\text { 14. Draw selective } \\
\text { extraction of relevant } \\
\text { points from a text }\end{array}$ & & $\begin{array}{l}\text { Extract salient points to summarize } \\
\text { Transcode information to diagrammatic display }\end{array}$ & $\begin{array}{l}\text { Discussion } \\
\text { Description }\end{array}$ \\
\hline $\begin{array}{l}\text { 15. Use inferences of } \\
\text { various types to monitor } \\
\text { comprehension in line } \\
\text { with reading goals. }\end{array}$ & a) & $\begin{array}{l}\text { Check ongoing comprehension by constantly } \\
\text { making inferences of a text } \\
\text { Set questions in mind to keep reading in line } \\
\text { with reading goals }\end{array}$ & $\begin{array}{l}\text { Procedure } \\
\text { Explanation }\end{array}$ \\
\hline $\begin{array}{l}\text { 16. Use scanning and } \\
\text { skimming. }\end{array}$ & a) & $\begin{array}{l}\text { Skimming } \\
\text { Scanning to locate specifically required } \\
\text { information } \\
\text { Start with specific questions to answer by } \\
\text { reading a text }\end{array}$ & $\begin{array}{l}\text { News items } \\
\text { (classified ads) } \\
\text { Exposition } \\
\text { )*everyday } \\
\text { texts (manuals, } \\
\text { labels, recipes) }\end{array}$ \\
\hline $\begin{array}{l}\text { 17. Practice rapid } \\
\text { recognition at word, } \\
\text { phrase and sentence } \\
\text { levels. }\end{array}$ & $\begin{array}{l}\text { a) } \\
\text { b) } \\
\text { c) } \\
\text { d) }\end{array}$ & $\begin{array}{l}\text { Identify content and functional words } \\
\text { Recognize rapidly identical words and phrases } \\
\text { Recognize rapidly key words/phrases, } \\
\text { repetitions, synonyms or registers of specific } \\
\text { text types } \\
\text { Recognize rapidly paragraph organization }\end{array}$ & $\begin{array}{l}\text { Anecdote } \\
\text { Exposition } \\
\text { )* everyday } \\
\text { reading texts } \\
\text { (timetables, } \\
\text { graphs, road } \\
\text { signs) }\end{array}$ \\
\hline $\begin{array}{l}\text { 18. Apply reading } \\
\text { skills/strategies to other } \\
\text { skill(s) (speaking, } \\
\text { listening or writing) } \\
\text { and/or to L1 reading } \\
\text { activities }\end{array}$ & a) & $\begin{array}{l}\text { Draw comparison between L1 and L2 reading } \\
\text { skills and activities and identify their facilitative } \\
\text { or interfering roles } \\
\text { Evaluate learners own writing in terms of } \\
\text { phrasal-clausal-discourse level relationship } \\
\text { within similar text type(s) } \\
\text { Reflect on how learners can apply reading skills } \\
\text { to set expectation of what they will hear and to } \\
\text { help prepare their speech }\end{array}$ & $\begin{array}{l}\text { Students own } \\
\text { writing } \\
\text { Example of an } \\
\text { oral } \\
\text { presentation/le } \\
\text { cture }\end{array}$ \\
\hline
\end{tabular}


Taking texts as the unit of drawing communicative meanings and orienting to developing reading skills as its outcomes, the course, in some ways, adopts both genre- and skill-based syllabi. The course corresponds to genre-based approach as it places a text at a discourse level during the act of comprehension. Genre-based teaching is integral in every meeting in that any reading activities in the class will always start with activating learners' prior knowledge, experience, expectations and attracting their attention to text types, regardless of skills being targeted. In such class, activities on, for example, building predicting skill are to take place within the discussion of genre. Likewise, activities on developing skills of identifying grammatical and lexical cohesion devices in a text will still depart from learners' interaction with the structure and discourse features of the given text type. Accordingly, the course's contents in terms of the skills are sequenced from wholeto-part and go in linear way.

The syllabus (example is given below) is developed to allow the development of skills which move from top-down technique to skills specific to bottom-up fashion. The course however ends with activities that trigger the interaction of both techniques as learners practise their self-monitoring skills and learn to transfer the learned skills to other learning situations. Since the previous learned skills are however reviewed and practised in the subsequent meetings, learners are provided with opportunities to proceduralize and thus automatize the reading skills through exposures of a variety of text types. In this regard, choice of text types is largely determined by the text type's relevance with particular reading skills/strategies. Yet, the selection is also influenced by the similarity of the text types presented in other classes such as Writing II, Listening II, speaking II, and the need for exposing learners with various genres (Thai, 2009). Further, Paltridge (2001, p.4) argues that exposures to a variety of genres will equip learners with knowledge related to "the organizational and linguistic features of genres that they need to have command of in their academic disciplines and professions". 


\section{UNIT/Week: I/2}

\section{Skills/strategies:}

1. Previewing (drawing on prior knowledge) \& predicting

2. Use co-text (e.g. pictures, graphs, quotation) and context clues (beyond the text) to predict and set expectations from reading a text

3. Skimming (a text \& a book)

\section{Specific text types:}

Today's headlines (from The Jakarta Post), advertisement, manual, explanation

\section{Goal:}

1. To raise learners' awareness of reading as an active process on the part of readers

2. To develop learners' skills and sensitivity to what's in and beyond a text and how they help them get the meaning out of the text

3. To develop learners' skimming skill when reading a book or a text

\section{Activities:}

$\checkmark \quad$ Predict (individual) \& discuss ${ }^{1}$ what different headlines' titles in The Jakarta Post \& some Australian newspapers may convey (in pairs).

$\checkmark \quad$ Skim the headlines news and discuss whether their prediction is correct and what leads them to predict as they did.

$\checkmark$ Read a text about butterfly's life cycle with and without illustrations and discuss which is easier to read and understand.

$\checkmark \quad$ Discuss co-texts and contexts in ads in magazines \& Dagadu ${ }^{2}$ products and how they might help readers.

$\checkmark$ Do exercises on predicting/previewing \& skimming individually and discuss in pairs. 
Exercise 1: preview some titles (of articles or books) and write down vocabularies that you expect to find.

Exercise 2: read the first paragraph of a text and select (from 4 options) the paragraph that you think will follow. (continued until 4 paragraph)

$\checkmark \quad$ Tell to the class the title of the book they have chosen to read, so as to ensure no one is reading the same book.

$\checkmark \quad$ Skim their own book and tell their pair what is the result of their skimming.

$\checkmark \quad$ In class: discuss how they skimmed a book and how it is different from skimming an article.

\section{Language focus}

$\checkmark \quad$ Structures and vocabularies related to the given text types

For example: headlines $=$ phrase to clause; advertisement $=$ descriptive languages (noun phrase $\&$ adjectives), manual = finite verb (open, lift, plug), conjunctions = first, next, last, explanation $=$ simple present $\&$ conjunctions

$\checkmark$ Register specific to the given text types (for example vocabularies for scientific and less scientific texts)

\section{Learning autonomy/strategies}

Self-monitoring \& self-evaluation and peer-evaluation

Comprehension monitoring strategy

\section{Cultural awareness}

Aware of the difference(s) of convention between English and Indonesian headlines, advertisements, manual, and explanatory texts.

\section{UNIT/Week: II/3}

\section{Skills:}

Recognize discourse-level relationship and use this information to build and support comprehension 


\section{Specific text types:}

A range of different texts the students bring to the class (fincluding descriptive, recount, narrative, procedure, report, argumentative exposition, persuasive exposition, explanation except news items, advertisements, manual)

\section{Goal:}

1. To expose learners to different types of texts

2. To raise their awareness of how each text is constructed with specific discourse features (generic structures \& linguistic features)

3. To develop their sensitivity to recognize discourse features of different texts.

4. To expose them to top-to-down reading approach

\section{Activities:}

$\checkmark \quad$ Make a group of those bringing similar text types.

$\checkmark$ Mention what similarity(ies) that brought them as a group.

$\checkmark \quad$ In groups, outline the thought-to-be generic structures of those similar texts \& present to the class.

$\checkmark \quad$ Read the handout that presents different text types and the texts' generic structures \& linguistic features.

$\checkmark \quad$ Find the gaps between their own outlines and those presented in the handout (group's self-assessment).

$\checkmark \quad$ Understand texts as discourse (generic structures \& linguistic feature.

$\checkmark \quad$ Do exercises on rearranging several texts with reference to their generic structures and discuss in pairs.

$\checkmark \quad$ Do exercises on deciding ${ }^{3}$ which parts of a text that hold answers to comprehension questions at hand.

\section{Language focus}

Structure \& vocabulary typical to different genres or text types 


\section{Learning autonomy/strategies}

Synthesizing skills in identifying the pattern of discourse features in various text types.

Be aware of different reading strategies that they can use when reading.

Peer-learning

Part of curriculum development is designing tasks that meet the specified goals and objectives as well as the syllabus. To exemplify the development of task for this curriculum, this paper proposes two tasks integrating reading and vocabulary since the teaching of reading has been well associated with vocabulary improvement. Indeed, one of difficulties in processing reading has to do with the lack of vocabulary that reduces readers' lexical accessibility particularly in second language (L2) reading (Celce-Muria \& Olshtain, 2000, p.132). Despite many believe that reading will naturally enrich one's vocabulary attainment, research in reading shows that natural (extensive) reading has resulted in relatively small vocabulary gain and thus needs to be supplemented with other activities (Min, 2008). Loufer (2003 in Min, 2008) found that reading only activity brought about significantly less vocabulary growth compared to activities that involved reading and sentence completion and text composition. Drawing on Loufer's study, Min thus suggests that 'learners involved in productive word-focused tasks were more likely to recall words than those engaged in receptive tasks' (p.7). He further asserts that reading comprehension only yields less vocabulary gains than reading activity that comes with text-based vocabulary exercises.

Given the potential of reading to increase vocabulary growth, this paper is also set to design two tasks where productive vocabulary and reading activities are integrated. This task design departs from the goals of Reading II course, i.e. to develop learners' reading skills/strategies so as to make them a good reader. CelceMuria \& Olshtain (2000) claim that a good reader usually integrates both top-down and bottom-up reading fashions. When $\mathrm{s} /$ he finds an unfamiliar word for example, $\mathrm{s} /$ he will make use of his or her top-down strategy which is relating the text at hand to the prior knowledge s/he already has, in conjunction with his or her bottom-up strategy which allows him or her to use clues the text provides, to guess the word's 
meaning. Guessing meaning can, however, be of too much problem especially for L2 learners, when the text exhibits less sufficient context and the reader has low English proficiency. Guessing meaning has thus been of one greatest lexical difficulties L2 readers encounter. In that regard, the tasks this paper is developing will deal with a bottom-up reading strategy which is guessing meaning from context within the discussion of recount text type.

Recount is often part of L2 learners' language repertoires particularly when they come to the job of describing things that happened to them. Producing and understanding a recount are thus a must-have language skill. The vocabulary to be dealt with in the tasks concerns English verbs particularly past verbs including both regular and irregular. The choice is made because recounts usually require a good deal of different uses of verbs in different tenses. Anderson and Anderson (1997) outline a sample of recount text type and do the discourse analysis on it. They explain that a recount text usually has a) an/a 'introduction that gives an orientation, b) sequence of events that recount the past in the order in which the events occurred, and c) concluding paragraph' (p.52). They also describe that it often uses descriptive words, proper nouns, past tense and words showing when. Understanding or producing a recount text coincides with the students' morphological range. As previously mentioned, the students have acquired past irregular and are about to learn past regular (-ed). Since recounts display a range of English past tense verbs, they are very potential to enhance learners' already acquired tense (irregular past) while promoting their acquisition of regular past ed. In this way, the students' proficiency and morphological development levels make them ready to work with the designed tasks.

The tasks designed in this paper depart from the characteristics of a dictogloss (DG) task. DG is typified with four procedures: preparation, dictation, reconstruction, and analysis with correction (Wajnryb, 1990 in Qin, 2008). DG is mainly discourse-oriented for stressing on meaning as a text (Thornburry, 1997 in Qin, 2008). The tasks will thus start with the pre-reading activities. The first prereading activity aims to brainstorm and activate their background knowledge related to the text. The text used for this design is about 'The X Files' movie. Movie is the chosen theme for its common popularity among young adults. The prereading activity then moves to discussion on the discourse structures of recount text type where the writer will display an example of recount with the analysis of its text type characteristics. The discussion will expose learners to the knowledge of 
text type and therefore prepares them to the main activity, which is reconstruction. Knowing how a recount is usually structured and what linguistic features are often found in recounts will certainly familiarize them to recounts and hence help them make their own.

The main reading activities of the designed tasks are at dictation and reconstruction stages of DG activities. The DG task in this design however will not involve dictation but expose learners with a reading text. In this way, the DG is modified to make learning productive and receptive vocabulary possible. The dictation phase of DG is substituted with a reading activity which promotes receptive vocabulary learning. In the reading phase, learners are not merely to read to later reconstruct a text but also to notice the verbs found in the text. The verbs to pay attention to are in the text and will be determined prior to the reading. After reading the text, the writer will take the text from the students who will then start reconstructing the text using their own language.

The reconstruction task in DG actually resembles free recall reading task suggested by Anderson (2000). Free recall, which is a task where test-takers read a short text within a time limit and immediately write down what they can recall from the text, Anderson argues, most carries authentic reading processes (p.230). The reconstruction text allows the students to improve their productive vocabulary through writing. To help them reconstruct, they are advised to use their knowledge of the discourse features of a recount. While reconstructing, they will compare their own language with that of the text. This will lead them to notice the targeted vocabulary or structure if the text is deliberately made to occupy the lexical and grammar which the learners are to acquire (Qin, 2008). The chosen text should thus need to contain a good number of past verbs and recount seems to fit in the criterion. The reconstruction is an individual task but open to pair discussion. The peer-discussion is expected to illuminate the language related episodes - 'occasions where L2 learners discuss or question their language use while carrying out a reconstruction task in L2' (Qin, 2008, pp.63-64). During the discussion, the students are expected to exchange on ideas of the meaning of the verbs that they do not know yet since they cannot use dictionaries. In so doing, they are also to build learning autonomy through collaborative works with peers (Klapper, 2006).

After the main activities, the students move to post-reading activities. The activities will first begin with the text analysis with correction, which is typical of DG tasks. The analysis will first look at whether the discourse features of a recount 
text type are found in the reconstructed writing. To do so, they will be given a piece of paper containing a template of recount's discourse features with labels on each of its sides (below, Anderson \& Anderson, 1997, p.52).

\begin{tabular}{|l|l|l|}
\hline Structure & \multicolumn{1}{|c|}{ The X Files } & Features \\
\hline $\begin{array}{l}\text { Introduction that gives } \\
\text { an orientation }\end{array}$ & $\begin{array}{l}\text { The X Files is one of televisions most popular shows, } \\
\text { watched each week by millions of people over sixty } \\
\text { countries. }\end{array}$ & $\begin{array}{l}\text { Descriptive } \\
\text { words }\end{array}$ \\
\hline $\begin{array}{l}\text { Sequence of events } \\
\text { that recount the past in } \\
\text { the order in which the } \\
\text { events occurred }\end{array}$ & $\begin{array}{l}\text { The show was created by Chris Carter, a former } \\
\text { magazine editor, who always wanted to make a cool and } \\
\text { scary television series. His idea for The X Files came } \\
\text { after he saw the results of a survey that said three out of } \\
\text { every hundred Americans believed that aliens had } \\
\text { captured them. } \\
\text { Carter next step was to produce a pilot episode, which } \\
\text { was to be the beginning of the series. When it was } \\
\text { shown on American television it received poor reviews. } \\
\text { After a while the audience grew and The X Files } \\
\text { became popular with both adults and teenagers. By this } \\
\text { time Carter was able to spend more on production. }\end{array}$ & Past tense \\
\hline Concluding paragraph & $\begin{array}{l}\text { The X Files has been nominated for awards and } \\
\text { continues to attract a growing audience }\end{array}$ & when \\
\hline
\end{tabular}

The template has boxes which have to be connected to the corresponding paragraph where the features are found. The analysis will also focus on the reconstruction of the past verbs in the students' recounts to see whether they keep their meaning the same. Doing so, the students are made to notice the gap between their language and that of the text. When the gap noticed, they are to retain the vocabulary longer. This correction stage will be done in the same pair where they asses each other's writing and judge how accurate their reconstruction. Last but most importantly, they have to provide suggestions how the verbs can be written more accurately or appropriately to make the meaning more similar to their originally intended meaning.

The last post-reading activity in these designed tasks is vocabulary exercise. In the exercise, the students deal further with vocabulary work in two steps. First, the writer will explain about clues they can find in a text to assist them guess a word's meaning. The clues are contextual and textual clues. While the first have been reinforced by discussing the discourse features of recount and linguistic features typical to recount, the later focuses on the grammatical function of a word. Though in this task they are to isolate verbs only, in reading they often need to 
translation surely difficult to gain an absolute similarity for each language has its own uniqueness, either grammatical or cultural meaning. The one who translate any documents must consider on the limitation of deriving faithful translation in which an SL text must be the same as the TL text.

Catford (1969: 20) agrees to both of arguments above that translation is the replacement of textual material in the Source Language text by equivalent textual material in the Target Language text. However, this definition seems limited on the use of textual material terms because translation is not only limited to the use of something textual but also untextual material, as described by Roman Jacobson as an intersemiotic translation. Therefore, this definition focuses more on the textual analysis rather than the meaning of a translated text proven by the famous approach of translation' shifts'.

Overall, the most comprehensive definition supporting process-oriented translation is derived by McGuire (1980) via Machali (1998: 1),

Translation is the rendering of a source language (SL) text into the target language (TL) so as to ensure that (1) the surface meaning of the two will be preserved as closely as possible but not so closely that the TL structures will be seriously distorted (McGuire, 1980: 2)

This definition has covered almost all similar ideas presented before, that translation is indeed a process that begun with the prefix re-. It means that translation does not take only once in its process but also twice or more processes. The idea of similarity is also argued as something impossible that the demand of translation as a process is near with making the natural and closest equivalence. Barely is the process of translation demanded to be the same.

\section{Function-Oriented DTS}

This view somehow leads three prominent translation scholars: Reiss, Vermeer, and Nord blush the functional theories of translation. 'Functionalist' in Nord (1997: 1) is defined as focusing on the function or that texts and translations have certain functions. Among the three functionalist theories, skopos theory by Vermeer, Translational Text-Analysis by Nord, and Text Type and Language Function by Reiss, the one who has played a major role in the development of functionalist trend is skopostheorie. Vermeer as explained by Munday (2001: 80) says that the term 'skopos' is the Greek word for 'purpose' or 'objectives'. It was introduced into translation theory in the 1970 s by Vermeer as a technical term for the action of translating and as a purpose of a translation. This definition 
p.84). In that way, the students are to also develop into a strategic reader who is aware of how to make the most of what is available in a text to assist their comprehension and ultimately achieve their reading purpose (McCarthy, 1991).

With regard to assessment, some types of assessment namely formative and summative tests, performance assessment (reading report \& summary) and participation/contribution are employed in this Reading course. Based on test purpose, Brown (2004, p.6), Hughes (2003, p.5, pp.12-15) and McNamara (2000, p.6), group summative test under achievement test, distinguishing summative from formative test or final from progress achievement test. Hughes explains that summative assessment is "used at, say, the end of the term, semester or year in order to measure what has been achieved both by groups or individuals". Formative test is mainly aimed at measuring students' learning progress and does not necessarily involve formal testing. Yet, this course will use written tests for both formative and summative assessments. To assess the tests' quality, Bachman and Palmer's (1996) test usefulness criteria are adopted. The criteria involve "a balance of the following six complementary qualities: reliability, construct validity, authenticity, interactiveness, impact and practicality" (pp.19-40).

To meet construct validity, the tests should be in line with what is taught in the class (Bahman \& Palmer). The formative test tests the skills taught before the test takes place (Unit 2 5) and the summative one assesses the skills taught in unit 6 - 13. To assess students' reading performance, various test tasks and techniques are used. In testing reading, Anderson states that "a task can take a number of different formats, or utilise a number of different techniques" (2000, p.202). He further argues that good reading tests often use different techniques either within the same text or across a variety of texts. The tests' tasks thus will resemble the reading tasks done in the class but tested integratedly, not one skill at a time as in discrete-point approach, because real reading process often necessitates different tasks and techniques (Anderson, 2000).

The techniques used in a test should also address the authenticity needs. Direct testing is a test that bests represent authentic language use (Hughes, 2003). However, when a test is constrained by practicality issues, Bachman and Palmer (1996) advise to have a balance between reflecting teaching and the use of language in real life. While the authentic performance in this course is assessed through reading report and summary, the course also attempts to make the tests communicative enough through some techniques suggested by Anderson (2000, 
pp.207-256). The techniques used in the formative test include gap-filling, multiple matching, ordering, short answers, and free recall, across descriptive, expository (essay), and news items text types. Anderson explains that gap filling technique can test an overall understanding of a text by removing the words which are crucial to the text's main ideas or which hold its coherence (p.210). Multiple matching techniques can be very effective to assess previewing, predicting, recognizing main ideas and patterns of paragraph organization by for example 'matching headings for paragraphs to their corresponding paragraph, titles of books against extracts from each book' (p.215). Ordering is very popular with paragraph organizations and main ideas identification while short answers are common to comprehension check. Free recall where test-takers read a short text within a time limit and immediately write down what they can recall from the text, Anderson argues, most carries authentic reading processes (p.230).

In the summative test, the techniques involve short answer, multiple matching, editing, summarizing into a table or chart across text types such as story, advertisement, and manual. Short answer technique can be used for guessing meaning, inferencing or scanning tasks. Moreover, Anderson argues that short answer is the one of the techniques that 'come closer to the real world' (p.249). Likewise, editing and summarizing are often done in everyday reading. These three techniques are also likely to address criteria of interactiveness and impact. They are interactive as they engage test-takers as readers to activate various language skills and prior knowledge. They give impact because they will give positive backwash to learning as what they are tested corresponds to what they have learned and done in various learning situations (Bachman \& Palmer, 1996). Yet, the downside is such techniques will elicit varied responses and thus necessitate a measure to lessen the scoring subjectivity. Where human judgment and decision are called, there would never be an objective marking since "rating always contains a significant degree of chance, associated with the rater and other factors" (McNamara 2000, p.37). To increase the scoring objectivity, the course will develop models of the expected responses (such as answer key) as a guideline in scoring as well as conducting inter-rating in scoring. Inter-rating can be done by having two examiners assessing a response and comparing their assessment to meet an agreed judgment (Hughes, 2003).

With regard to test procedure, both tests are paper and pen test take 90 minutes with no dictionary use. The formative test will be held in the same time as 
the class schedule and in the same classroom. The teacher will proctor the formative test but possibly not the summative test. The proctor, time and room of the summative test will however be arranged by the Faculty. The Faculty also requires minimum attendance for students to be able to attend final tests. The course therefore considers participation and contribution as an assessment component since without sufficient attendance students cannot participate or contribute maximally. The tests, reading report and summary and participation/contribution will make up the overall assessment that determines the students' passing the course with minimum mark of C.

In terms of course evaluation, this course will employ summative evaluation approach. Graves (2000, p.215) states that summative evaluation of a course will determine the course's continuity, degree of achievement, redesigning. Brown (1995) and Tomlinson (2003) add that curriculum evaluation should inform whether the course has met the students' needs. In terms of course contents, they particularly evaluate whether the contents met the construct or conceptualization of the subject and were well organized. Tomlinson further emphasizes the role of materials in making teaching and learning process successful as part of curriculum evaluation. While being summative in nature, the evaluation of the course will adopt product-oriented approach. Brown (1995) describes product evaluation as focusing on 'whether the goals (products) of the program are being achieved' (p.227). Since this course aims to develop reading skills, whether or not it has attained the goal has to be determined by at least the result of students' tests, which are also made to assess the skills. Brown classifies test scores as quantitative data in course evaluation. Since he argues that course evaluation should combine both quantitative and qualitative data, this course will also be evaluated by administering student's feedback sheet given at the end of the course, and if possible, classroom observation.

\section{CONCLUSION}

To conclude, this curriculum is developed to address the needs of the students while taking heed of the two-fold goals of teaching reading in the Department. The tasks design illustrates the classroom activities which promote the use of reading skills and strategies through both top-down and bottom-up approaches to reading process while facilitating students' familiarity and understanding of different genres. 


\section{REFERENCES}

Anderson, J. C. (2000). Assessing reading. UK:CUP

Bachman, L. and A. Palmer. (1996). Language testing in practice. Oxford: OUP.

Brown, H. D. (1994). Teaching by principles: an interactive approach to language pedagogy. Englewood Cliffs, New Jersey: Prentice Hall Regents.

Brown, H.D. (2004). Language assessment: principles and classroom practices. NY: Longman

Brown, J.D. (1995). The elements of language curriculum. a systematic approach to program development. Massachusetts, USA: Heinle \& Heinle Publishers

Celce-Muria, M. \& Olshtain, E. (2000). Discourse and Context in language teaching: a guide for language teachers. NY: CUP

DeKeyser, R. (2007). Skill Acquisition Theory. In VanPatten, B. \& Williams, J. (Eds.). Theories in second language acquisition. Mahwah, NJ: Routledge.

Genesee, F. \& Upshur, J.A. (1996). Classroom-based evaluation in second language education. Cambridge: CUP

Grabe, William. (2009). Reading in a second language: moving from theory to practice. NY: CUP

Graves, K. (2000). Designing Language Courses: A Guide for Teachers. Boston, MA: Heinle and Heinle.

Graves, K. (2008). The language curriculum: a social contextual perspective. Language Teaching, 41(2), 147-181.

Grellet, F. (1981). Developing reading skills: a practical guide to reading comprehension exercises. UK: CUP

Harmer, J. (2007). The practice of English language teaching ( $4^{\text {th }} \mathrm{ed}$.). Essex: Longman

Hughes, A. (2003). Testing for language teachers. $\left(2^{\text {nd }}\right.$ ed.). Cambridge: CUP.

Klapper, J. (2006). Understanding and developing good practice: language teaching in higher education. London: The National Centre for Languages. 
Lightbown, Patsy. M. \& Spada, N. (2006). How languages are learned. ( $3^{\text {rd }}$ ed.). NY: OUP

Lin, B. (2006). Genre-based teaching and Vygotskian principles in EFL: the case of a university writing course. Asian EFL JOURNAL, 8(3).

McNamara, T. (2000). Language Testing. Oxford: OUP.

Nunan, D. (1988). Syllabus Design. Oxford: OUP

Nunan, D. (2004). Task-based language teaching. Cambridge: CUP

Paltridge, B. (2001). Genre and the language learning classroom. Michigan: Ann Arbor.

Rea-Dickins, P. \& Germaine, K. (2003). Purposes for evaluation. In D.R. Hall \& A. Hewings (Eds.)., Innovation in English language teaching: a reader. NY: Routledge

Richards, J. (2001). Curriculum Development in Language Teaching. Cambridge: CUP

Thai, Minh D. (2009). Text-based language teaching. NSW: Mazmania Press

Tomlinson, B. (2003). Materials evaluation. In B. Tomlinson, Developing materials for language teaching, (pp.15-36). London: Continuum

Ur, P. (1996). A course in language teaching. Practice and theory. UK:CUP

Wajnryb, R. 1992.Classroom Observation Tasks, Cambridge: CUP 